\title{
BIOAKTIVITAS EKSTRAK BIJI BINTARO TERHADAP KUTU DAUN Aphis gossypii GLOVER DAN PENGARUHNYA TERHADAP TANAMAN CABAI
}

\section{BIOACTIVITY OF Cerbera odollam G. SEED EXTRACT ON Aphis gossypii Glover AND THEIR EFFECTS ON PEPPER}

\author{
Rial Mustiarif ${ }^{1}$, Djamilah $^{1}$, Nanik Setyowati $^{2 *}$, Agustin $^{2}$ arkani ${ }^{1}$ \\ 1Jurusan Perlindungan Tanaman, Fakultas Pertanian, Universitas Bengkulu \\ 2Jurusan Budidaya Pertanian, Fakultas Pertanian, Universitas Bengkulu \\ Jln. W.R. Supratman, Bengkulu 38371 \\ *Korespondensi: nsetyowati@unib.ac.id
}

Diterima : 29 April 2020 / Disetujui : 28 November 2020

\begin{abstract}
ABSTRAK
Aphis gossypii Glover hama penting tanaman cabai, dapat dikendalian dengan menggunakan pestisida nabati. Penelitian bertujuan untuk mengevaluasi waktu aplikasi dan konsentrasi ekstrak kasar biji bintaro (Cerbera odollam G.) dalam mengendalikan A. gossypii Glover serta pengaruhnya terhadap pertumbuhan tanaman cabai. Penelitian menggunakan Rancangan Acak Lengkap, dua faktor dan tiga ulangan. Faktor pertama adalah waktu aplikasi ekstrak (waktu sebelum dan waktu setelah infestasi $A$. gossypii Glover). Faktor kedua adalah konsentrasi ekstrak bintaro (0\%, 1\%, 2\%, 3\%, 4\% dan 5\%). Hasil penelitian menunjukkan konsentrasi $1 \%$ ekstrak biji bintaro menyebabkan mortalitas kutu daunnya 68\% sedangkan pada konsentrasi $3 \%$ mortalitasnya mencapai $90 \%$. Ekstrak biji bintaro yang diberikan sebelum hama diinfestasikan menyebabkan mortalitas kutu daun $59,5 \%$ sedangkan jika diberikan setelah hama diinfestasikan mortalitasnya meningkat menjadi $77,6 \%$. Nilai $\mathrm{LC}_{50}$ dan $\mathrm{LC}_{90}$ ekstrak biji bintaro diaplikasikan sebelum dan setelah hama diinfestasikan secara berurutan adalah $1,8 \% ; 4,4 \% ; 0,57 \%$ dan $2,8 \%$. A. gossypii Glover yang diinfestasikan pada tanaman berumur 4 minggu dan disemprot dengan ekstrak biji bintaro pada konsentrasi $1 \%$ dapat menurunkan intensitas kerusakan pada hari ke tujuh setelah infestasi dan tidak berpengaruh terhadap jumlah daun, bobot segar maupun bobot kering tanaman cabai. Ekstrak biji bintaro dapat dikembangkan sebagai pestisida nabati untuk mengendalikan hama $A$. gossypii Glover pada tanaman cabai.
\end{abstract}

Kata kunci: Aphis gossypii Glover, bintaro, cabai, insektisida nabati, kutu daun

\begin{abstract}
Aphis gossypii Glover is an important sucking insect pest of the pepper (Capsicum annum L.), Can be controlled by using natural pesticides. The study aimed to evaluate the application time and concentration of Cerbera odollam G. seed extract in controlling A. gossypii and their effects on pepper, $C$. annum. Complete randomized design was used in this experiment, with two factors, and was repeated three times. The first factor was the time of application of the extract, consisting of before and after $A$. gossypii infestation. The second factor was the concentration of $C$. odollam extract $(0 \%, 1 \%, 2 \%, 3 \%, 4 \%$ and $5 \%)$. The results indicated the $C$. odollam seed
\end{abstract}


extract affected the mortality of $A$. gossypii. At a concentration of $1 \%$ of $C$. odollam seed extract, the mortality of $A$. gossypii was $68 \%$ while at a concentration of $3 \%$ the mortality reached up to $90 \%$. C. odollam seed extract applied before infestation, the mortality of $A$. gossypii was $59.5 \%$ whereas, after the infestation, the mortality increased up to $77.6 \% . \mathrm{LC}_{50}$ and $\mathrm{LC}_{90}$ extract of $C$. odollam seeds applied before and after infestation were $1.8 \% ; 4.4 \% ; 0.57 \%$ and $2.8 \%$ respectively. A. gossypii infested at 8 weeks old pepper and sprayed with $C$. odollam seed extract at a concentration of $1 \%$ lowered the crop damage on the seventh day after infestation. On the other hand, the application of $C$. odollam seed extract did not affect the number of leaves, fresh weight, and dry weight of pepper. This study indicate that $C$. odollam seed extract can be developed as a natural pesticide to control $A$. gossypii on pepper.

Keywords: Aphis gossypii , bioactivity, Cerbera odollam, natural insecticide, pepper

\section{PENDAHULUAN}

Salah satu hama penting tanaman cabai (Capsicum sp.) yang dibudidayakan baik secara organik maupun konvensional adalah kutu daun, Aphis gossypii Glover (Hemiptera: Aphididae) (Saroinsong, 2014). Selain menyerang tanaman secara langsung, kutu daun juga berperan sebagai vektor penyakit virus tanaman seperti virus keriting dan virus kerdil. Kehilangan hasil tanaman yang disebabkan serangga hama ini dapat mencapai $35 \%$ sedangkan dampak kerusakannya sebagai vektor virus jauh lebih tinggi, mencapai 90\% (Khodijah, 2014). Serangga $A$. gossypii bersifat polifag yang menyerang hampir semua spesies tanaman cabai dan legum dengan waktu serangan tertinggi terjadi pada musim kemarau. Umumnya, nimfa dan imago menyerang daun yang masih muda. Tusukan stilet yang terdapat pada alat mulut pencucuk penghisap serangga akan menyebabkan nekrotik, kerutan dan gulungan sehingga tanaman tumbuh secara tidak normal (Purnama \& Susilawati, 2014).

Pengendalian kutu daun $A$. gossypii biasanya dilakukan dengan pestisida kimia sintetik. Akan tetapi, penggunaan senyawa racun kimia sintetik yang tidak bijak dapat menimbulkan dampak negetif terhadap lingkungan seperti hilangnya musuh alami hama dan serangga polinator serta menimbulkan residu racun bagi ternak dan manusia (Mahmood et al., 2016). Untuk mengurangi dampak negatif pestisida sintetik tersebut, maka diperlukan alternatif lain yaitu menggunakan pestisida berbahan ramah lingkungan seperti pestisida nabati. Petisida nabati selain aman, efektif, bahan baku mudah tersedia juga karena pertimbangan harga (Kamarulzaman et al., 2012). Teknik pengendalian ini selanjutnya dapat dipadukan dengan teknik pengendalian ramah lingkungan lainnya dalam sistem pengendalian hama terpadu (Aryawan \& Rahardjo, 2013; Indiati and Marwoto, 2017; Tulipia \& De, 2019).

Sumber pestisida nabati banyak ditemukan dan tumbuh baik di lingkungan ekosistem tropis Indonesia. Beberapa jenis tanaman asli nusantara telah diketahui memiliki kandungan zat-zat kimia metabolit sekunder cukup tinggi yang berpotensi untuk dikembangkan sebagai pengendalian berbagai jenis hama tanaman secara komersial (Dono et al., 2012). Beberapa jenis tanaman yang telah digunakan secara luas sebagai bahan pengendalian hama tanaman diantaranya adalah serai (Cymb opogo citratus), serai wangi (Cynubopogon nardus), jeringau (Acorus calamus), babandotan 
(Ageratum conyzoides), jarak pagar (Jatropha curcas L.) (Saenong, 2016).

Selain itu, tanaman bintaro (Cerbera odollam G.) adalah tanaman yang juga berpotensi sebagai pestisida nabati. Biji buah bintaro mengandung senyawa aktif flavonoid, steroid, saponin dan tanin yang bersifat racun pada serangga (Utami et al., 2010) sehingga sering digunakan petani untuk pengendalian hama pada tanaman (Tarmadi et al., 2014). Konsentrasi 2\% ekstrak biji bintaro diketahui dapat menghambat pembentukan pupa pada Spodoptera litura (Sa'diyah et al., 2013) sedangkan ekstrak daun dan daging buah bintaro bersifat racun terhadap larva Eurema spp. (Utami, 2010). Penelitian ini bertujuan untuk menentukan konsentrasi ekstrak kasar biji bintaro terbaik dalam mengendalikan kutu daun $A$. gossypii beserta waktu aplikasinya dan pengaruh ekstrak tersebut terhadap pertumbuhan tanaman cabai merah (C. annuum).

\section{BAHAN DAN METODE}

Penelitian dilaksanakan pada bulan November 2015 - Januari 2016 di Laboratorium Proteksi Tanaman dan Kebun Percobaan Fakultas Pertanian, Universitas Bengkulu. Rancangan yang digunakan yaitu acak lengkap (RAL) dengan 2 faktor perlakuan. Faktor pertama adalah waktu aplikasi ekstrak biji bintaro yang terdiri dari $\mathrm{A}_{1}=$ ekstrak diberikan sebelum infestasi hama $A$. gossypii dan $\mathrm{A}_{2}=$ ekstrak diberikan setelah infestasi hama $A$. gossypii. Faktor kedua adalah konsentrasi ekstrak biji bintaro yang terdiri dari $\mathrm{P}_{0}=0 \% ; \mathrm{P}_{1}=1 \% ; \mathrm{P}_{2}=2 \% ; \mathrm{P}_{3}$ $=3 \% ; P_{4}=4 \%$; dan $P_{5}=5 \%$. Setiap kombinasi perlakuan diulang tiga kali.

\section{Pemeliharaan dan Perbanyakan Kutu Daun}

Kutu daun yang diperoleh dari tanaman cabai di sekitar lahan percobaan organik milik Fakultas Pertanian, Universitas Bengkulu diperbanyak di Laboratorium. Perbanyakan dilakukan pada tanaman cabai yang ditanam dalam polibag yang berukuran $17,5 \mathrm{~cm} \times 40,0 \mathrm{~cm}(p \times t)$ dengan media tanam berupa campuran tanah dan pupuk kandang perbandingan volume 2:1.

\section{Persiapan Media Tanam Cabai}

Media tanam untuk tanaman cabai sama seperti media tanam yang digunakan untuk tujuan pemeliharaan dan perbanyakan kutu daun.

\section{Penanaman dan Pemeliharaan Cabai}

Masing-masing satu bibit cabai yang telah berumur 4 minggu dan sudah membentuk daun 4-6 helai ditanam dalam polibag yang telah terisi media tanam. Tanaman disiram dua kali sehari pada pagi dan sore hari sejak tanaman dalam persemaian hingga 5 minggu setelah tanam (MST). Pupuk urea sebanyak 2 g tanaman ${ }^{-1}$ diberikan pada 3 MST. Pengendalian gulma dilakukan secara manual dengan mencabut setiap tanaman liar yang tumbuh di dalam polibag.

\section{Pembuatan Ekstrak Biji Bintaro}

Biji bintaro yang digunakan untuk pembuatan ekstrak uji diambil dari bagian kotiledon tanpa kulit biji pada buah bintaro yang telah masak sempurna. Ekstraksi dilakukan dengan cara memblender $1000 \mathrm{~g}$ biji bintaro dengan air suling sebanyak 800 $\mathrm{ml}$ hingga menjadi bubur dan kemudian didiamkan selama 24 jam. Selanjutnya bubur biji disaring dengan menggunakan kertas saring. Ampas yang tersisa kemudian diperas, ditambahkan air suling dan diperas kembali sehingga jumlah akhir ekstrak mencapai $1000 \mathrm{ml}$. Hasil dari penyaringan ini 
digunakan sebagai larutan stok yang kemudian dipersiapkan sebagai larutan ekstrak uji dengan konsentrasi $1 \%, 2 \%, 3 \%$, $4 \%$ dan $5 \%$.

\section{Infestasi Hama dan Aplikasi Ekstrak}

Kutu daun A. gossypii instar akhir dan atau dewasa sebanyak 30 ekor diinfestasikan ke setiap tanaman uji. Pemindahan nimfa dilakukan dengan menggunakan kuas pada saat tanaman berumur 4 MST. Penyemprotan ekstrak biji bintaro pada tanaman cabai dilakukan pada sore hari dengan menggunakan hand sprayer ke seluruh bagian tanaman. Aplikasi ekstrak dilakukan satu kali, yaitu dua jam sebelum kutu daun diinfestasikan pada tanaman $\left(A_{1}\right)$ dan 12 jam setelah kutu daun diinfestasikan pada tanaman $\left(A_{2}\right)$. Dosis ekstrak uji yang digunakan adalah $15 \mathrm{ml}$ per tanaman.

Variabel yang diamati meliputi, Mortalitas kutu daun yang diamati setiap hari sejak awal aplikasi ekstrak hingga 7 hari setelah perlakuan. Persentasi mortalitas dihitung dengan membagi total jumlah serangga hidup di hari pengamatan dengan total jumlah serangga hidup dihari sebelumnya. Perubahan tingkah laku dan morfologi kutu daun dilakukan sejak aplikasi hingga 7 hari dengan cara mengamati gerakan, warna dan ukuran kutu daun akibat perlakuan. Tingkat kerusakan tanaman diamati pada akhir pengamatan dengan cara menghitung daun yang rusak dan selanjutnya dilakukan pengkategorian ke skala kerusakan (Tabel 1) serta menghitung jumlah daun untuk setiap tanaman yang diamati. Jumlah daun dan tingkat kehijauan daun diamati 2 kali dengan menggunakan SPAD-meter sebelum aplikasi ekstrak dan pada akhir penelitian (5 MST). Bobot segar dan bobot kering tanaman diamati pada akhir penelitian.

Tabel.1 Nilai dan kategori serangan kutu daun A.gossypii.

\begin{tabular}{clcl}
\hline Nilai & \multicolumn{1}{c}{ Kategori } & Persentase $(\%)$ & Kategori Serangan \\
\hline 0 & tidak ada serangan pada daun & 0 & normal \\
1 & $1 / 8$ bagian daun menggulung & $>0-25$ & ringan \\
2 & $1 / 4$ bagian daun menggulung & $>25-50$ & sedang \\
3 & $1 / 2$ bagian daun menggulung & $>50-75$ & berat \\
4 & $>1 / 2$ bagian daun menggulung & $>75$ & sangat berat \\
\hline
\end{tabular}

\section{Analisis Data}

Data hasil pengamatan dianalisis dengan menggunakan Anova $\left(F_{5 \%}\right)$ dan uji lanjut BNT. Nilai $\mathrm{LC}_{50}$ dan $\mathrm{LC}_{90}$ dihitung dengan analisis probit menggunakan program statistika Minitab 16.

\section{HASIL DAN PEMBAHASAN}

\section{Mortalitas dan Perubahan Tingkah Laku} Kutu Daun

Hasil penelitian menunjukkan ekstrak biji bintaro berpengaruh terhadap kematian kutu daun dengan tingkat mortalitas yang beragam (Tabel 2). Konsentrasi ekstrak bintaro $1 \%$ dapat mengakibatkan kematian kutu daun sebesar 70\%, namun daya toksisitasnya tidak berbeda nyata dengan uji konsentrasi 2\%. Mortalitas kutu daun tertinggi didapatkan pada konsentrasi 5\% yaitu mencapai $94 \%$ terhadap kematian serangga uji, A. gossypii, meskipun tidak berbeda nyata dengan perlakuan 3\% dan $4 \%$. Dengan demikian konsentrasi uji ekstrak biji bintaro 3\% memberikan hasil terbaik secara 
ekonomis dengan kemampuan toksisitas optimal.

Hasil penelitian ini menguatkan apa yang dilaporkan Utami (2010) bahwa ekstrak biji bintaro pada konsentrasi $1 \%$ dapat mengakibatkan mortalitas serangga uji hingga 90\%. Kandungan bahan racun tidak hanya terdapat pada biji buah, namun bagian daun tanaman bintaro pada konsentrasi $2 \%$ telah dilaporkan dapat menurunkan berat pupa, menghambat proses penggantian kulit dan pembentukan pupa S. litura (Sa'diyah et al., 2013).

Tabel 2. Total mortalitas kutu daun, Aphis gossypii pada berbagai konsentrasi ekstrak biji bintaro pada hari ke-7 setelah aplikasi

\begin{tabular}{|c|c|}
\hline Konsentrasi Ekstrak (\%) & Mortalitas (\%) \\
\hline \multirow{2}{*}{0} & $5,55 \mathrm{c}$ \\
\hline & 5,55 \\
\hline \multirow{2}{*}{1} & $70,00 \mathrm{~b}$ \\
\hline & 68,32 \\
\hline \multirow{2}{*}{2} & $71,11 b$ \\
\hline & 69,40 \\
\hline \multirow{2}{*}{3} & $90,55 \mathrm{a}$ \\
\hline & 89,99 \\
\hline \multirow{2}{*}{4} & $85,00 \mathrm{a}$ \\
\hline & 84,05 \\
\hline \multirow{2}{*}{5} & $94,44 a$ \\
\hline & 94,10 \\
\hline
\end{tabular}

Keterangan : Angka-angka yang diikuti huruf yang berbeda pada kolom yang sama menunjukkan berbeda nyata pada uji lanjut beda nyata terkecil (BNT) taraf $5 \%$.Angka-angka yang ditulis miring adalah angka mortalitas yang sudah dikoreksi dengan rumus Abbot.

Hama kutu daun memiliki kepekaan terhadap senyawa aktif ekstrak biji bintaro pada batas konsentrasi tertentu. Kepekaan serangga terhadap senyawa racun tanaman disebabkan oleh antara lain penurunan mobilitas larva dan menurunnya nafsu makan (Sari et al., 2013). Selain itu, pertahanan serangga terhadap racun dapat berupa perilaku menghindar, ekskresi dan penyerapan bertahap toksin (Ibanez et al., 2012).

Tanaman bintaro diketahui mengan-dung saponin, flavonoid, steroid dan tanin yang dapat meracuni serangga (Utami, 2010; Sarwar, 2015). Tanin dan saponin merupakan senyawa bioaktif tanaman yang bersifat racun terhadap serangga (Saenong, 2016) sedangkan senyawa flavonoid seperti asam klorogenik, quersetin dan rutin yang terdapat pada banyak tanaman dapat mengganggu proses fisiologis dan pergantian kulit (moulting) pada serangga (Jadhav et al., 2012) serta bekerja sebagai racun respirasi sel dengan cara mempengaruhi kinerja enzim pada mitokondria (Vandock et al., 2012). Alkaloid umumnya dikenal sebagai senyawa yang mempunyai efek toksin dan berdampak langsung terhadap perkembangan metamorfosa serangga (Saenong, 2016).

Kematian kutu daun juga diduga karena kandungan minyak yang terdapat pada biji 
menyumbat spirakel sehingga mengganggu sistem pernapasan serangga. Fraksi ester dari minyak biji beberapa tanaman berpotensi untuk digunakan sebagai perlindungan tanaman dari serangan hama (Ratnadass \& Wink, 2012). Biji bintaro mengandung kadar minyak yang cukup tinggi yaitu sekitar 51,07 \% (Handayani et al., 2015). Minyak yang dihasilkan dari biji bintaro mengandung anti mikroba dan racun yang telah digunakan untuk pengobatan kudis dan membasmi kutu kepala (Syakir, 2011).

Mortalitas kutu daun pada tanaman cabai juga dipengaruhi oleh waktu aplikasi. Penyemprotan ekstrak biji bintaro setelah kutu daun diinfestasikan ke tanaman cabai berdampak kepada mortalitas lebih tinggi dibandingkan dengan aplikasi sebelum hama diinfestasikan (Tabel 3). Hal ini dikarenakan aplikasi ekstrak setelah hama diinfestasikan memiliki mekanisme kerja ganda yaitu sebagai racun kontak saat serangga terpapar bahan aktif dan sebagai racun sistemik ketika serangga menghisap tanaman. Sebaliknya, jika aplikasi ekstrak dilakukan sebelum hama diinfestasikan, maka bahan aktif ekstrak hanya bersifat racun sistemik saja. Pengujian ekstrak tanaman sebagai racun sistemik lokal dan racun kontak pada hama telah dilaporkan (Siahaya \& Rumthe, 2014).

Tabel 3.Pengaruh waktu aplikasi terhadap mortalitas kutu daun pada tanaman cabai

\begin{tabular}{ll}
\hline Waktu Aplikasi Ekstrak & Mortalitas (\%) \\
\hline Sebelum hama diinfestasikan & $60,92 \mathrm{~b}$ \\
& 59,52 \\
Setelah hama diinfestasikan & $77,96 \mathrm{a}$ \\
& 77,62
\end{tabular}

Keterangan : Angka-angka yang diikuti oleh huruf yang sama pada kolom yang sama berbeda tidak nyata pada uji lanjut Beda Nyata Terkecil (BNT) taraf 5\%.

Angka-angka yang ditulis miring adalah angka mortalitas yang telah dikoreksi dengan rumus Abbot.

Hasil penelitian ini juga menunjukkan bahwa morfologi dan tingkah laku kutu daun setelah aplikasi ekstrak biji bintaro mengalami perubahan. Nimfa kutu daun yang terpapar ekstrak mengalami keracunan, geraknya tidak terarah, kejangkejang, perlahan warna nimfa semakin gelap, mengecil dan kemudian mati. Gejala keracunan serangga terhadap pestisida nabati telah dijelaskan oleh Nechiyana et al. (2011) yaitu perubahan morfologi kutu daun terlihat pada warna tubuh dan kondisi tubuh. Utami (2010) menjelaskan larva $S$. lituras setelah aplikasi ekstrak kasar daun bintaro tubuhnya cenderung berubah ke arah kehitaman dan mengecil serta kaku dan berkeriput dengan gerak yang lambat menjauhi daun serta tubuh berubah warna menjadi kehitaman.

\section{Pengaruh Ekstrak Biji Bintaro terhadap Populasi Kutu Daun}

Ekstrak biji bintaro dapat menurunkan populasi kutu daun pada tanaman cabai di lapangan. Dinamika populasi kutu daun pada tanaman di setiap perlakuan dapat dilihat pada Gambar 3. Penurunan populasi kutu daun pada ekstrak uji yang diberikan sebelum hama diinfestasikan terlihat hingga pengamatan hari ke-5, namun populasi 
meningkat pada hari ke-6 hingga hari ke-8

(Gambar 3A.).
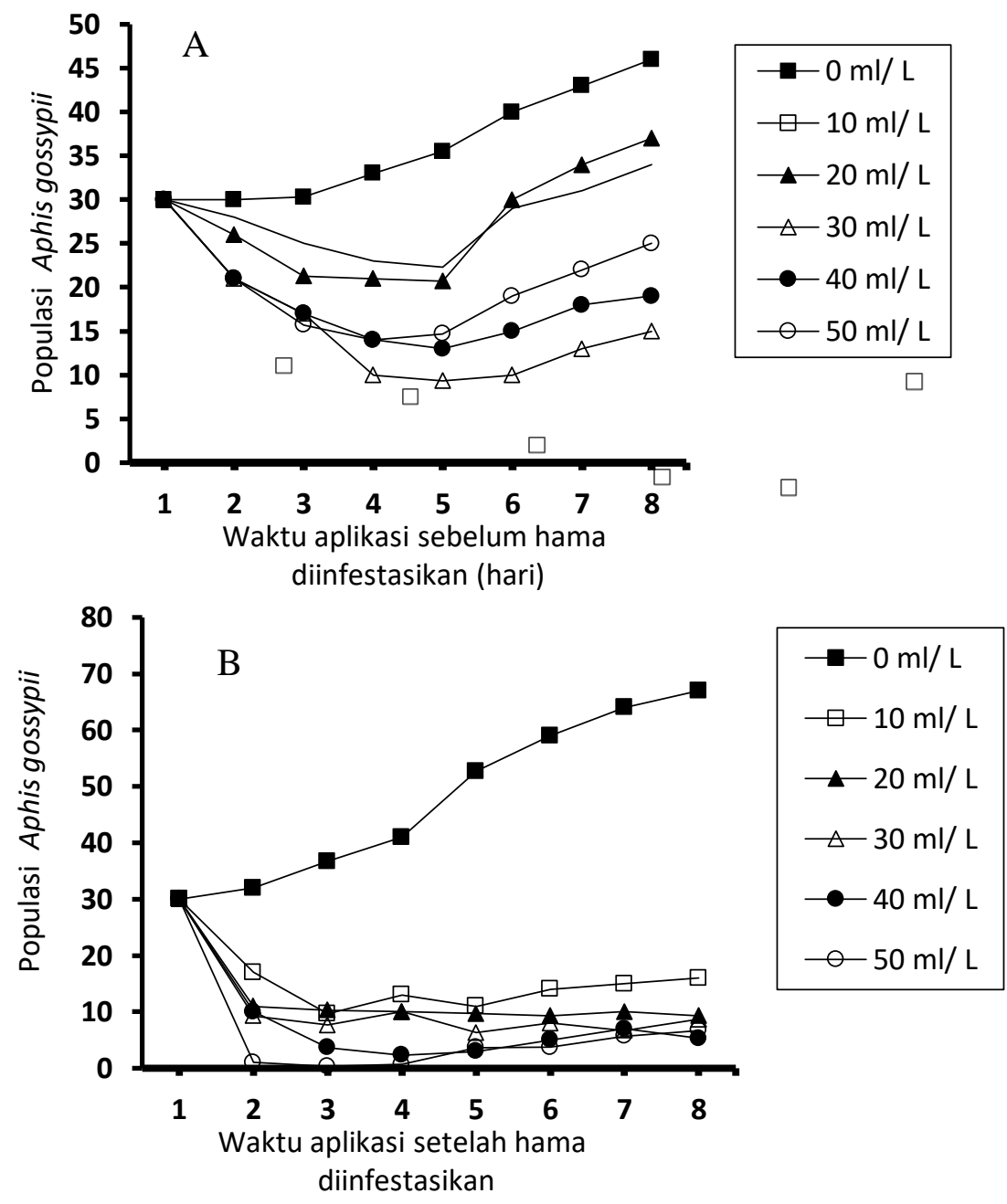

Gambar 3. Dinamika populasi kutu daun Aphis gossypii selama 7 hari pengamatan pada berbagai konsentrasi ekstrak biji bintaro A. Sebelum kutu daun diinfestasikan B. Setelah kutu daun diinfestasikan.

Kondisi yang sama juga terjadi pada ekstrak uji yang diberikan setelah hama diinfestasikan yaitu peningkatan konsentrasi dapat menurunkan populasi kutu daun hingga hari ke-4, namun populasi meningkat pada hari ke-5 hingga hari ke-8 (Gambar 3B). Peningkatan populasi kutu daun pada hari ke-5 diduga karena perkembangbiakan nimfa resisten yang masih bertahan hidup serta adanya infestasi baru imago bersayap kutu daun dari tanaman sekitarnya. Perkembangbiakan kutu daun ini sangat cepat yaitu seekor betina dapat menghasilkan 28-32 nimfa baru setiap harinya (Irsan et al., 2010) Penyebab lainnya karena dampak residu racun ekstrak biji bintaro di tanaman cabai telah hilang pada hari ke-5 sehingga tidak lagi menjadi faktor penghambat bagi perkembangbiakan kutu daun. Yolanda (2013) menyatakan bahwa 
pestisida nabati memiliki sifat yang mudah terurai dan tidak tahan terhadap sinar matahari sehingga aplikasi harus dilakukan berulang-ulang.

Pengujian berbagai konsentrasi ekstrak biji bintaro terhadap tanaman cabai menunjukkan bahwa konsentrasi dan waktu aplikasi tidak berpengaruh terhadap beberapa parameter pertumbuhan tanaman kecuali pada kehijauan daun 5 MST dan intensitas kerusakan tanaman (Tabel 4).

\section{Hasil Uji Lanjut Beda Nyata Terkecil}

Konsentrasi ekstrak biji bintaro berpengaruh terhadap intensitas kerusakan dan kehijauan daun pada 5 MST, namun tidak berpengaruh terhadap jumlah daun pada 4 dan 5 MST, kehijauan daun 4 MST, bobot segar maupun bobot kering berangkasan (Tabel 4 dan Tabel 5).

Tabel 4. Hasil analisis varian pengaruh waktu aplikasi dan konsentrasi ekstrak biji bintaro terhadap pertumbuhan tanaman cabai

\begin{tabular}{lccc}
\hline \multirow{2}{*}{ Variabel Pengamatan } & \multicolumn{3}{c}{ Nilai F hitung 5\% } \\
\cline { 2 - 4 } & Waktu Aplikasi & Konsentrasi & Interaksi \\
\hline Intensitas kerusakan & $0,41 \mathrm{~ns}$ & $16,39^{*}$ & $0,42 \mathrm{~ns}$ \\
Jumlah daun 4 MST & $0,28 \mathrm{~ns}$ & $0,66 \mathrm{~ns}$ & $1,36 \mathrm{~ns}$ \\
Jumlah daun 5 MST & $0,03 \mathrm{~ns}$ & $1,90 \mathrm{~ns}$ & $1,36 \mathrm{~ns}$ \\
Kehijauan daun 4 MST & $0,02 \mathrm{~ns}$ & $1,31 \mathrm{~ns}$ & $1,17 \mathrm{~ns}$ \\
Kehijauan daun 5 MST & $1,07 \mathrm{~ns}$ & $7,82 *$ & $1,77 \mathrm{~ns}$ \\
Bobot basah berangkasan & $0,16 \mathrm{~ns}$ & $1,22 \mathrm{~ns}$ & $0,64 \mathrm{~ns}$ \\
Bobot kering berangkasan & $0,30 \mathrm{~ns}$ & $1,86 \mathrm{~ns}$ & $1,67 \mathrm{~ns}$ \\
\hline
\end{tabular}

Keterangan: *: berpengaruh nyata; ns: berpengaruh tidak nyata; MST : minggu setelah tanam.

Ekstrak biji bintaro pada konsentrasi 5\% menyebabkan kerusakan tanamannya terendah yaitu 6,90\% dan tidak berbeda nyata dengan konsentrasi uji lainnya. Ekstrak biji bintaro pada konsentrasi $1 \%$ sudah dapat menurunkan tingkat kerusakan tanaman dari sedang ke rendah. Selain itu, ekstrak biji bintaro juga dapat mempertahankan tingkat kehijauan daun tanaman pada 4 MST (Tabel 5). Peningkatan konsentrasi ekstrak biji bintaro dengan demikian dapat mempertahankan tanaman dari kerusakan dan kehilangan pigmen hijau daun oleh kutu daun. Kehijauan daun tertinggi didapatkan dari konsentrasi 5\%. Diduga, dengan konsentrasi yang semakin meningkat, kadar bahan aktif dalam larutan juga meningkat yang diikuti dengan efektivitasnya yang juga meningkat sehingga intensitas kerusakan tanaman menurun.

Keberadaan kutu daun pada tanaman cabai bukan hanya sebagai hama, akan tetapi juga berperan sebagai vektor penyakit virus keriting (Khodijah, 2014). Penyakit umumnya dapat menurunkan laju fotosintesis dengan mengurangi jumlah klorofil pada daun (Tuhumury \& Amanupunyo, 2013). Bahkan, aktivitas makan kutu Aphid sitobion Avenae diketahui dapat mempengaruhi karatenoid dan klorofil tanaman (Wójcicka, 2014).

Tanaman bintaro positif mengandung saponin, flavonoid, steroid dan tanin. Selain itu biji bintaro juga mengandung senyawa cerberin yang merupakan golongan alkaloid/glikosida yang bersifat racun 
(Utami, 2010). Senyawa cerberin merupakan senyawa glikosid yang menghambat saluran ion $\mathrm{K}$ dalam otot jantung yang dapat menghentikan detak jantung yang berakibat kematian (Prasanth \& Aiyalu, 2015; Prasanth \& Rajasekaran, 2015). Senyawa glikosid dapat digunakan sebagai racun perut, racun kontak, repellent, confusant, yang dapat menghambat aktivitas biologi hama (Sarwar, 2015). Wulandari et al. (2014) menyatakan pertumbuhan dan perkembangan serangga hama berkorelasi terhadap kualitas makanan yang dimakan.

Tabel 5. Pengaruh konsentrasi ekstrak biji bintaro terhadap intensitas kerusakan dan kehijauan daun tanaman cabai

\begin{tabular}{ccc}
\hline $\begin{array}{c}\text { Konsentrasi Ekstrak } \\
(\%)\end{array}$ & Intensitas Kerusakan (\%) & Kehijauan Daun (5 HST) \\
\hline 0 & 47,16 a (sedang) & $45,07 \mathrm{c}$ \\
1 & $13,65 \mathrm{~b}$ (ringan) & $60,65 \mathrm{ab}$ \\
2 & $13,52 \mathrm{~b}$ (ringan) & $61,46 \mathrm{ab}$ \\
3 & $12,05 \mathrm{~b}$ (ringan) & $56,50 \mathrm{~b}$ \\
4 & $9,60 \mathrm{~b}$ (ringan) & $66,78 \mathrm{a}$ \\
5 & $6,90 \mathrm{~b}$ (ringan) & $67,23 \mathrm{a}$ \\
\hline
\end{tabular}

Keterangan: angka- angka yang diikuti oleh huruf yang sama pada kolom yang sama berbeda tidak nyata pada uji lanjut pada taraf $5 \%$.

Kutu daun yang hidup pada tanaman cabai yang sudah terpapar racun pestisida, aktivitas biologinya akan terganggu, metabolisme tubuh terhambat dan menyebabkan kematian. Akibatnya kerusakan tanaman maupun kehilangan pigmen hijau daun dapat ditekan (Tabel 6).

Tabel 6. Tingkat kehijauan daun cabai pada 4 MST dan 5 MST pada berbagai konsentrasi ekstrak biji bintaro yang diaplikasikan sebelum kutu daun diinfestasikan $\left(A_{1}\right)$ dan setelah diinfestasikan $\left(A_{2}\right)$

\begin{tabular}{ccccc}
\hline \multirow{2}{*}{$\begin{array}{c}\text { Konsentrasi Ekstrak } \\
(\%)\end{array}$} & \multicolumn{4}{c}{ Tingkat Kehijauan Daun } \\
\cline { 2 - 5 } & Waktu Aplikasi $\mathrm{A}_{1}$ & Waktu Aplikasi $\mathrm{A}_{2}$ \\
\cline { 2 - 5 } & $4 \mathrm{MST}$ & $5 \mathrm{MST}$ & $4 \mathrm{MST}$ & $5 \mathrm{MST}$ \\
\hline 0 & 55,26 & 49,96 & 54,56 & 40,16 \\
1 & 59,93 & 66,83 & 59,63 & 54,46 \\
2 & 55,63 & 57,23 & 58,83 & 65,70 \\
3 & 51,76 & 58,46 & 56,60 & 54,53 \\
4 & 60,30 & 65,70 & 54,86 & 67,86 \\
5 & 58,03 & 66,93 & 55,13 & 67,53 \\
\hline
\end{tabular}

Konsentrasi ekstrak biji bintaro tidak berpengaruh terhadap jumlah daun (Tabel 4, Tabel 7). Meskipun tidak berpengaruh terhadap jumlah daun, namun serangan hama kutu daun $A$. gossypii Glover menimbulkan kerusakan pada daun. Tipe kerusakan daun yang terjadi sesuai dengan 
tipe mulut kutu daun yaitu pencucuk penghisap (Purnama \& Susilawati, 2014).

Hasil yang sama ditunjukkan pada variabel bobot segar dan bobot kering tanaman. Perbedaan konsentrasi dan waktu aplikasi ekstrak tidak berpengaruh terhadap bobot brangkasan tanaman (Tabel 8).
Hasil penelitian Anggraini et al. (2018) menunjukkan, serangan kutu daun pada tanaman cabai mempengaruhi tinggi tanaman, jumlah buah maupun ukuran buah yang pada akhirnya menurunkan hasil panen cabai.

Tabel 7.Pengaruh konsentrasi dan waktu aplikasi ekstrak biji bintaro terhadap jumlah daun cabai pada 4 dan 5 MST

\begin{tabular}{ccccc}
\hline \multirow{2}{*}{$\begin{array}{c}\text { Konsentrasi Ekstrak } \\
(\%)\end{array}$} & \multicolumn{4}{c}{ Jumlah Daun } \\
\cline { 2 - 5 } & \multicolumn{2}{c}{ Waktu Aplikasi $\mathrm{A}_{1}$} & \multicolumn{2}{c}{ Waktu Aplikasi $\mathrm{A}_{2}$} \\
\cline { 2 - 5 } & $4 \mathrm{MST}$ & $\mathrm{MST}$ & $4 \mathrm{MST}$ & $5 \mathrm{MST}$ \\
\hline 0 & 14,33 & 10,66 & 24,33 & 23,00 \\
1 & 25,66 & 24,33 & 28,33 & 31,33 \\
2 & 22,00 & 24,00 & 23,33 & 22,33 \\
3 & 40,00 & 20,66 & 15,66 & 13,00 \\
4 & 30,00 & 28,66 & 38,33 & 40,33 \\
5 & 35,66 & 36,00 & 21,33 & 19,00 \\
\hline
\end{tabular}

Keterangan: ekstrak diberikan sebelum hama diinfestasikan $\left(A_{1}\right)$ dan ekstrak diberikan setelah hama diinfestasikan $\left(\mathrm{A}_{2}\right)$.

Penelitian lain juga menyatakan hal yang serupa yaitu aktivitas makan hama pencucuk penghisap Thrip pada mulberri (Morus alba L.) berpengaruh terhadap komposisi biokimia (asam amino, protein total terlarut, total gula pereduksi, total gula larut, pati dan jumlah fenol) dan pigmen fotosintesis (jumlah klorofil, klorofil-a, klorofil-b, dan karotenoid). Perubahan komposisi biokimia pada tanaman tersebut dapat mempengaruhi pertumbuhan tanaman Mahadeva (2011).

Tabel 8.Pengaruh konsentrasi dan waktu aplikasi ekstrak terhadap bobot segar dan bobot kering tanaman cabai pada 5 MST

\begin{tabular}{ccccc}
\hline \multirow{2}{*}{$\begin{array}{c}\text { Konsentrasi Ekstrak } \\
(\%)\end{array}$} & \multicolumn{2}{c}{ Bobot Segar Tanaman (g) } & \multicolumn{2}{c}{ Bobot Kering Tanaman (g) } \\
\cline { 2 - 5 } & $\begin{array}{c}\text { Waktu } \\
\text { Aplikasi A }\end{array}$ & $\begin{array}{c}\text { Waktu } \\
\text { Aplikasi A }\end{array}$ & $\begin{array}{c}\text { Waktu } \\
\text { Aplikasi } A_{1}\end{array}$ & $\begin{array}{c}\text { Waktu } \\
\text { Aplikasi A }\end{array}$ \\
\hline 0 & 30,00 & 40,00 & 8,33 & 16,66 \\
1 & 50,00 & 45,00 & 16,66 & 13,33 \\
2 & 46,66 & 43,33 & 15,00 & 10,00 \\
3 & 38,33 & 30,00 & 15,00 & 8,33 \\
4 & 56,66 & 73,33 & 18,33 & 33,33 \\
5 & 63,33 & 33,33 & 20,00 & 8,33 \\
\hline
\end{tabular}

Keterangan: ekstrak diberikan sebelum hama diinfestasikan $\left(\mathrm{A}_{1}\right)$ dan ekstrak diberikan setelah hama diinfestasikan $\left(A_{2}\right)$. 
Serangan kutu daun juga dapat menyebabkan penurunan yang signifikan pada klorofil, gula larut, nitrogen total, protein total, total asam amino bebas dan IAA sebagai komponen pembentuk biomasa tanaman yang mana semakin besar bobotnya mengindikasikan proses fotosintesis berjalan dengan baik (El-Khawas \& El-Khawas, 2008).

Ketahanan tanaman terhadap kutu daun dikendalikan oleh gen Daryanto et al. (2017). Varietas tanaman dengan demikian menentukan ketahanannya terhadap infestasi kutu daun. Cabai keriting galur MG1012 lebih tahan terhadap serangan katu daun dibandingkan varietas Kiyo, Jinggo maupun Lado (Mukhtadhor et al., 2017). Hasil ini sejalan dengan penelitian yang telah dilakukan, bahwa serangan kutu daun tidak menunjukkan pengaruh negatif terhadap bobot segar maupun bobot kering berangkasan tanaman pada $5 \mathrm{MST}$, namun pengamatan tidak dilanjutkan sampai panen.

\section{$\mathrm{LC}_{50}$ dan LC 90 Ekstrak Biji Bintaro pada Kutu Daun Aphis gossypii}

Nilai Lethal Concentration $\left(\mathrm{LC}_{50}\right)$ dan $\mathrm{LC}_{90}$ ekstrak biji bintaro yang diaplikasikan sebelum hama kutu daun diinfestasikan lebih besar dibandingkan dengan $\mathrm{LC}_{50}$ dan $\mathrm{LC}_{90}$ setelah hama diinfestasikan (Tabel 9). Konsentrasi yang mampu untuk mematikan serangga uji pada $\mathrm{LC}_{50}$ adalah $1,765 \%$ dan $0.565 \%$ masing-masing untuk perlakuan sebelum dan setelah hama diinfestasikan. Sedangkan konsentrasi yang tepat untuk mengendalikan serangga uji pada $\mathrm{LC}_{90}$ adalah $2,775 \%$ setelah hama diinfestasikan dan $4.359 \%$ sebelum hama diinfestasikan.

Hal ini terjadi karena mortalitas hama bukan hanya dipengaruhi oleh tingkatan konsentrasi tapi juga dipengaruhi oleh waktu aplikasi. Penentuan nilai LC ini bertujuan untuk menentukan konsentrasi ekstrak biji bintaro yang direkomendasikan untuk aplikasi di lapangan dimana batas optimal dari konsentrasi suatu pestisida untuk pengendalian hama tertentu adalah $\mathrm{LC}_{90}$.

Tabel 9. Konsentrasi efektif $\mathrm{LC}_{50}$ dan $\mathrm{LC}_{90}$ ekstrak biji bintaro yang diaplikasikan sebelum hama diinfestasikan dan setelah hama diinfestasikan

\begin{tabular}{lcc}
\hline \multicolumn{1}{c}{ Waktu Aplikasi } & Derajat Kematian (LC) & $\begin{array}{c}\text { Konsentrasi Ekstrak } \\
(\%)\end{array}$ \\
\hline Sebelum hama diinfestasikan & 50 & 1,765 \\
Sebelum hama diinfestasikan & 90 & 4,359 \\
Setelah hama diinfestasikan & 50 & 0,565 \\
Setelah hama diinfestasikan & 90 & 2,775 \\
\hline
\end{tabular}

Jika aplikasi ini membunuh $100 \%$ serangga sasaran, maka perlakuan tersebut justru dapat mengakibatkan terganggunya populasi musuh alami hama karena makanannya menjadi tidak tersedia. Konsentrasi ekstrak optimal untuk mengendalikan kutu daun yaitu 3\% yang diaplikasikan sebelum maupun setelah hama diinfestasikan.

\section{SIMPULAN}

Kesimpulan yang dapat ditarik dari penelitian ini adalah: 
1. Konsentrasi ekstrak biji bintaro $1 \%$ menghasilkan mortalitas kutu daun sebesar $70 \%$ sedangkan pada konsentrasi ektrak 3\% meningkat menjadi 90,55\%.

2. Aplikasi ekstrak biji bintaro sebelum hama diinfestasikan mengakibatkan mortalitas kutu daun sebesar 59,52\% sedangkan aplikasi setelah hama diinfestasikan mortalitasnya menjadi $77,62 \%$.

3. $L C_{50}$ dan $L_{90}$ ekstrak biji bintaro yang diaplikasikan sebelum dan setelah hama diinfestasikan masing-masing secara berurutan adalah 1,77\%; 4,36\%; 0,57\% dan $2,78 \%$.

4. Ekstrak biji bintaro dapat menurunkan intensitas kerusakan tanaman dan tidak berdampak negatif terhadap pertumbuhan tanaman cabai pada 5 minggu setelah tanam.

\section{DAFTAR PUSTAKA}

Anggraini, K., Yuliadhi, K.A., Widaningsih, D. (2018). Pengaruh Populasi Kutu Daun pada Tanaman Cabai Besar (Capsicum Annuum L.) terhadap Hasil Panen. Agroekoteknologi Tropika 7, 113-121.

Aryawan, A.A.K., Rahardjo, B.T. (2013). Potensi asap pembakaran tempurung kelapa dalam pengendalian hama Rhyzopertha dominica F. (Coleoptera: Bostrichidae) pada gabah dalam simpanan. J. HPT 1, 6-15.

Daryanto, A., Syukur, M., Maharijaya, A., Hidayat, P. (2017). Pewarisan Sifat Ketahanan Cabai terhadap Infestasi Aphis gossypii Glover (Hemiptera: Aphididae). J. Hortik. Indones. 8, 39. https://doi.org/10.29244/jhi.8.1.3947

Dono, D., Natawigena, W.D., Majid, M.G. (2012). Bioactivity of methanolic seed extract of Barringtonia asiatica L. (Kurz) (Lecythidaceae) on biological characters of Spodoptera litura (Fabricius) (Lepidoptera: Noctuidae). Int. Res. J. Agric. Sci. Soil Sci. 2, 469-475.

El-Khawas, S.A.M., El-Khawas, M.A.M. (2008). Interactions between Aphis gossypii (Glov.) and the common predators in eggplant and squash fields, with evaluating the physiological and biochemical aspects of biotic stress induced by two different aphid species, infesting squash and cabbage Plants. Aust. J. Basic Appl. Sci. 2, 183-193.

Handayani, R., Rukminita, S., Gumilar, I. (2015). Karakteristik fisiko-kimia minyak biji bintaro (Cerbera manghas L) dan potensinya sebagai bahan baku pembuatan biodiesel. Jurnal Akuatika VI(2), 177-186.

Ibanez, S., Gallet, C., Després, L. (2012). Plant insecticidal toxins in ecological networks. Toxins 4, 228-243. https://doi.org/10.3390/toxins 4040 228

Indiati, S.W., Marwoto, M. (2017). Penerapan Pengendalian Hama Terpadu (PHT) pada tanaman kedelai. Bul. Palawija 15, 87-100. https://doi.org/10.21082/bulpa.v15 n2.2017.p87-100

Irsan, C., Wati, C., Herlinda, S., Pujiastuti, Y. (2010). Biologi kutu daun Lapaphis erysimi Kalt (Hemiptera: Aphididae) di tumbuhan inang yang berbeda, in: Seminar Nasional PEI. Presented at the Seminar Nasional PEI, PEI Pusat, Jogyakarta, p. 11.

Jadhav, D.R., Mallikarjuna, N., Rathore, A., Pokle, D. (2012). Effect of Some Flavonoids on Survival and Development of Helicoverpa armigera (Hübner) and Spodoptera litura (Fab) (Lepidoptera: 
Noctuidae). Asian J. Agric. Sci. 4, 298-307.

Kamarulzaman, N.H., Mazlan, N., Rajendran, S.D., Mohayidin, M.G. (2012). Role of biopesticides in developing a sustainable vegetable industry in Malaysia. Int. J. Green Econ. 6, 243. https://doi.org/10.1504/IJGE.2012. 050973

Khodijah (2014). Kelimpahan serangga predator kutu daun Aphis gossypii di sentra tanaman sayuran di Sumatera Selatan. Biosaintifika 6 , 76-84.

Mahadeva, A. (2011). Influence of thrips (Pseudodendrothrips mori) infestation on the biochemical constituents and photosynthetic pigments of mulberry (Morus spp,) leaves. Int. J. Plant Anim. Environ. Sci. 1, 57-63.

Mahmood, I., Imadi, S.R., Shazadi, K., Gul, A., Hakeem, K.R. (2016). Effects of Pesticides on Environment, in: Hakeem, K.R., Akhtar, M.S., Abdullah, S.N.A. (Eds.), Plant, Soil and Microbes. Springer International Publishing, Cham, pp. 253-269.

https://doi.org/10.1007/978-3-31927455-3_13

Mukhtadhor, M., Suharjono, F., Rahayu, S., 2017. Uji ketahanan galur cabai keriting MG1012 (Capsicum annum L.) terhadap hama kutu daun persik (Myzus persicae Sulz). Agriprima J. Appl. Agric. Sci. 1, 126-133. https://doi.org/10.25047/agriprima. v1i2.46

Nechiyana, Sutikno, A., Salbiah, D., 2011. Penggunaan ekstrak daun pepaya (Carica papaya L,) untuk mengendalikan hama kutu daun (Aphis gossypii Glover) pada tanaman cabai (Capsicum annum L.). Universitas Riau, Riau.
Prasanth, S.S., Aiyalu, R. (2015). Quantitative determination of cerberin in seed extract of Cerbera odollam and rat serum by high performance thin layer chromatography. J. Appl. Pharm. Sci. 5, 61-69.

Prasanth, S.S., Rajasekaran, A. (2015). Derivative ultra-violet spectroscopic method for the estimation of cerberin in rat plasma. Int. J. Pharma Bio Sci. 6, 749-758.

Purnama, Y., Susilawati, E. (2014). Hama dan Penyakit pada Tanaman Cabai serta Pengendaliannya. Balai Pengkajian Teknologi Pertanian, Jambi.

Ratnadass, A., Wink, M. (2012). The phorbol ester fraction from Jatropha curcas seed oil: potential and limits for crop protection against insect pests. Int. J. Mol. Sci. 13, 16157-16171. https://doi.org/10.3390/ijms13121 6157

Sa'diyah, N.A., Purwani, K.I., Hakim, J.A.R. (2013). Pengaruh ekstrak daun bintaro (Cerbera odollam) terhadap perkembangan ulat grayak (Spodoptera litura F.). J. Sains Dan Seni Pomits 2, 2337-3520.

Saenong, M.S. (2016). Tumbuhan Indonesia potensial sebagai insektisida nabati untuk mengendalikan hama kumbang bubuk jagung (Sitophilus spp.). J. Penelit. Dan Pengemb. Pertan. 35, 131-142. https://doi.org/10.21082/jp3.v35n3 .2016.p131-142

Sari, M., Lubis, L., Pangestiningsih, Y. (2013). Uji efektivitas beberapa insektisida nabati untuk mengendalikan ulat grayak (Spodoptera litura F.) (Lepidoptera: Noctuidae) di Laboratorium. J. Online Agroekoteknolog 1, 560-569.

Saroinsong, R.S. (2014). Inventarisasi JenisJenis Hama Pada Pertanaman Cabai (Capsicum annum L,) di Kelurahan Kakaskasen I, Kota Tomohon. 
Jurusan Hama dan Penyakit, Fakultas Pertanian, Universitas Sam Ratulangi, Manado.

Sarwar, M. (2015). The Killer Chemicals as Controller of Agriculture Insect Pests. The Conventional Insecticides 1, 123-128.

Siahaya, V.G., Rumthe, R.Y. (2014). Uji ekstrak daun pepaya (Carica papaya) terhadap larva Plutella xylostella (Lepidoptera: Plutellidae). Agrologia 3, 112-116. https://doi.org/10.30598/a.v3i2.25 1

Syakir, M. (2011). Bintaro (Cerbera odollam) sebagai pestisida nabati. War. Penelit. Dan Pengemb. Ind. 17, 1-6.

Tuhumury, G.N.C., Amanupunyo, H.R.D., (2013). Kerusakan tanaman cabai akibat penyakit virus di Desa Waimital Kecamatan Kairatu. Agrologia 2, 36-42. https://doi.org/10.30598/a.v2i1.27 6

Tulipia, D., De, L.C. (2019). Bio-pesticides: A viable tool for organic farming. Int. J. Microbiol. Res. 11, 1660-1664.

Utami, S. (2010). Aktivitas insektisida bintaro (Cerbera odollam Gaertn) terhadap hama Eurema spp. pada skala laboratorium. J. Penelit. Hutan Tanam. 7, 211-220. https://doi.org/10.20886/jpht.2010. 7.4.211-220

Vandock, K.P., Mitchell, M.J., Fioravanti, C.F. (2012). Effects of plant flavonoids on Manduca sexta (tobacco hornworm) fifth larval instar midgut and fat body mitochondrial transhydrogenase. Arch. Insect Biochem. Physiol. 80, 15-25. https://doi.org/10.1002/arch.21022

Wójcicka, A. (2014). Changes in pigment content of triticale genotypes infested with grain Aphid sitobion Avenae (fabricius) (homoptera: aphididae). Acta Biol. Cracoviensia Ser. Bot. 56, 121-127.

Wulandari, S., Oemry, S., Pangestiningsih, Y. (2014). Pengaruh tekstur butiran pada beberapa komoditas terhadap jumlah imago hama Sitophylus oryzae L. (Coleoptera: Curculionidae) di Laboratorium. J. Online Agroekoteknologi 2, 23376597.

Yolanda, K. (2013). Mengenal Pestsida Nabati. Balai Pengkajian Teknologi Pertanian, Bangka Belitung. 